\title{
Article \\ Protective Effect of Siegesbeckia orientalis on Pancreatic $\beta$-Cells under High Glucose-Induced Glucotoxicity
}

\author{
Chi-Chang Chang ${ }^{1,2, *}$, Jer-Yiing Houng ${ }^{3,4}{ }^{\oplus}$, Shih-Wei Wang ${ }^{5,6}$, Chin-Feng Hsuan ${ }^{5,7} \mathbb{(}$, Yung-Chuan Lu ${ }^{1,8} \mathbb{D}$, \\ Tzu-Hsien Chang ${ }^{2}$ and Ya-Ling Chen ${ }^{2}$
}

1 School of Medicine for International Students, College of Medicine, I-Shou University, Kaohsiung 82445, Taiwan; ed100369@edah.org.tw

2 Department of Obstetrics \& Gynecology, E-Da Hospital/E-Da Dachang Hospital, Kaohsiung 82445, Taiwan; andy3560133@gmail.com (T.-H.C.); ed109776@edah.org.tw (Y.-L.C.)

3 Department of Nutrition, I-Shou University, Kaohsiung 82445, Taiwan; jyhoung@isu.edu.tw

4 Department of Chemical Engineering, I-Shou University, Kaohsiung 82445, Taiwan

5 School of Medicine, College of Medicine, I-Shou University, Kaohsiung 82445, Taiwan; ed101397@edah.org.tw (S.-W.W.); ed102745@edah.org.tw (C.-F.H.)

6 Division of Allergy, Immunology, and Rheumatology, Department of Internal Medicine, E-Da Hospital, Kaohsiung 82445, Taiwan

7 Division of Cardiology, Department of Internal Medicine, E-Da Hospital/E-Da Dachang Hospital, Kaohsiung 82445, Taiwan

8 Division of Endocrinology and Metabolism, Department of Internal Medicine, E-Da Hospital, Kaohsiung 82445, Taiwan

* Correspondence: ed101779@edah.org.tw; Tel.: +886-7-6150011 (ext. 251168)

Citation: Chang, C.-C.; Houng, J.-Y.; Wang, S.-W.; Hsuan, C.-F.; Lu, Y.-C.; Chang, T.-H.; Chen, Y.-L. Protective Effect of Siegesbeckia orientalis on Pancreatic $\beta$-Cells under High Glucose-Induced Glucotoxicity. Appl. Sci. 2021, 11, 10963. https://doi.org/ 10.3390/app112210963

Academic Editor: Zhaohui Xue

Received: 21 October 2021

Accepted: 18 November 2021

Published: 19 November 2021

Publisher's Note: MDPI stays neutral with regard to jurisdictional claims in published maps and institutional affiliations.

Copyright: (c) 2021 by the authors. Licensee MDPI, Basel, Switzerland. This article is an open access article distributed under the terms and conditions of the Creative Commons Attribution (CC BY) license (https:/ / creativecommons.org/licenses/by/ $4.0 /)$.

\begin{abstract}
The glucotoxicity caused by long-term exposure of $\beta$-cells to high glucose (HG) conditions may lead to the generation of more reactive oxygen species (ROS), reduce the activity of antioxidant enzymes, cause cell damage and apoptosis, and induce insulin secretion dysfunction. Siegesbeckia orientalis linne is a traditional folk herbal medicine used to treat snake bites, rheumatoid arthritis, allergies, and immune deficiencies. In this study, we evaluated the protective effect of S. orientalis ethanol extract (SOE) on cell death and oxidative stress in RIN-m5f pancreatic $\beta$-cells stimulated by two HG concentrations (50-100 mM). In the cell viability assay, SOE could significantly increase the survival rate of pancreatic $\beta$-cells under HG-induced conditions. For the oxidative stress induced by HG condition, the treatment of SOE effectively reduced the ROS formation, increased the content of intracellular glutathione, and up-regulated the expression of antioxidant enzymes, catalase, superoxide dismutase, and glutathione peroxidase. As a result, the SOE treatment could decrease the glucotoxicity-mediated oxidative damage on RIN-m5F $\beta$-cells. Moreover, SOE had the function of regulating insulin secretion in pancreatic $\beta$-cells under different HG-mediated conditions. It could decrease the increasing intracellular insulin secretion under the low glucose concentration to normal level; while increase the decreasing intracellular insulin secretion under the relatively high glucose concentration to normal level. Taken together, this study suggests that SOE has a protective effect on pancreatic $\beta$-cells under the HG-stimulated glucotoxic environment.
\end{abstract}

Keywords: Siegesbeckia orientalis; pancreatic $\beta$-cells; glucotoxicity; oxidative stress; cell proliferation; antioxidant enzyme activity; insulin secretion

\section{Introduction}

Diabetes mellitus is a complicated metabolic disorder accompanied by hyperglycemia, mainly due to the inefficient secretion of insulin from the pancreatic $\beta$-cells, in conjunction with insulin resistance developed in cells, such as muscle, liver, etc. Normally, pancreatic $\beta$-cells, which are extremely sensitive to blood glucose level, maintain glucose homeostasis by secreting and releasing insulin. Chronic exposure to high glucose (HG) concentration (hyperglycemia) has adverse impacts (referred to as glucotoxicity) on $\beta$-cells: it reduces the 
insulin secretion, the sensitivity to glucose stimulation, and the response to insulinotropic stimuli. All these detrimental effects eventually cause the progressive deterioration of $\beta$-cell mass and function. Thus, the status of $\beta$-cells is essential in the pathogenesis of type 2 diabetes [1-3].

Elevated blood glucose level can increase production of advanced glycation endproducts (AGEs) [4-6] and cause mitochondria to produce excessive amounts of reactive oxygen species (ROS), which in turn raises the oxidative stress. Such oxidative stress and accumulated AGEs may contribute to $\beta$-cell dysfunction, apoptosis, tissue damage, and aging [7-11]. Furthermore, in addition to causing cell damage, apoptosis and insulin secretion dysfunction, glucotoxicity can also lead to decreased activity of antioxidant enzymes, such as catalase, glutathione peroxidase (GPx), and superoxide dismutase (SOD) [3,6]. Taking all these adverse events together, glucotoxicity increases the development of many diabetic complications and the difficulty of glycemic control [10,12,13]. Thus, it is important to find means to attenuate the hyperglycemia-induced oxidative stress and apoptosis to reduce the risk of such pathological damage caused by diabetes [3].

Some natural products, such as mulberry leaf, rooibos (Aspalathus linearis), Padina arborescens, Portulaca oleracea, Orthosiphon stamineus, and Stevia rebaudiana, have been shown to have the activity of alleviating hyperglycemic status by protecting the function of pancreatic $\beta$-cells [3,14-18].

Siegesbeckia orientalis linne is a folk herbal medicine used to treat waist and knee weakness, rheumatoid arthritis, bone pain, quadriplegia, traumatic bleeding, and immune deficiency. Previous studies have reported that $S$. orientalis ethanol extract (SOE) has significant anti-inflammatory, analgesic, and anti-hyperuricemic effects [19,20], immunosuppressive activity on mouse ovalbumin [21], and suppressive effects on the proliferation and metastasis of human cervical cancer cells and endometrial cancer cells [22-24].

Our previous paper demonstrated that SOE has significant antioxidant activity and inhibitory activity against $\alpha$-glucosidase, pancreatic lipase, angiotensin I-converting enzyme (ACE) and the formation of AGEs [25]. Thus, SOE has the potential to prevent and treat diabetes and metabolic disorders. However, so far there is no evidence that SOE can affect the growth and function of pancreatic $\beta$-cells. In this study, we aimed to explore whether SOE has the protective effect on HG-stimulated oxidative stress and death in pancreatic $\beta$-cells.

\section{Results}

\subsection{Effect on Proliferation of HG-Stimulated $\beta$-Cells}

The effect of glucose at different concentrations on the cell viability of RIN-m5f $\beta$ cells was examined. The experimental results in Figure 1A illustrate that the growth of $\beta$-cells was greatly inhibited as the glucose concentration increased. When the glucose concentration was increased to 50 or $100 \mathrm{mM}$, the cell survival rate dropped to $74.8 \%$ and $61.3 \%$ of the control group, respectively. This indicates that high glucose levels are cytotoxic to $\beta$-cells. In order to evaluate the application potential of SOE, this study chose to conduct related experiments under extremely severe conditions, i.e., 50 or $100 \mathrm{mM}$. Under these conditions, it is easier to observe the protective effect of SOE.

Next, we examined the effect of SOE at different concentrations on the proliferation of RIN-m5f $\beta$-cells. The results in Figure 1B show that SOE promoted the growth of $\beta$-cells at low concentrations $(<62.5 \mu \mathrm{g} / \mathrm{mL})$ but significantly inhibited cell proliferation at higher concentrations (125 and $250 \mu \mathrm{g} / \mathrm{mL})$. Compared with the control group, the cell viability of those treated with $250 \mu \mathrm{g} / \mathrm{mL}$ SOE was reduced by around $12 \%$.

We also examined whether addition of SOE at different concentrations could exert protective effects on the proliferation of cells stimulated with 50 or $100 \mathrm{mM}$ glucose. Figure $1 \mathrm{C}$ indicates that SOE could attenuate the glucotoxic effect of high glucose concentration on $\beta$-cells. This protective effect became more obvious with the increase of SOE concentration and was concentration-dependent. When the SOE concentration increased to $250 \mu \mathrm{g} / \mathrm{mL}$, 
its protective effect approaches that of $50 \mu \mathrm{M}$ metformin (positive control), a clinical drug used with the activities of anti-oxidative stress and antiglycation [26,27].

(A)

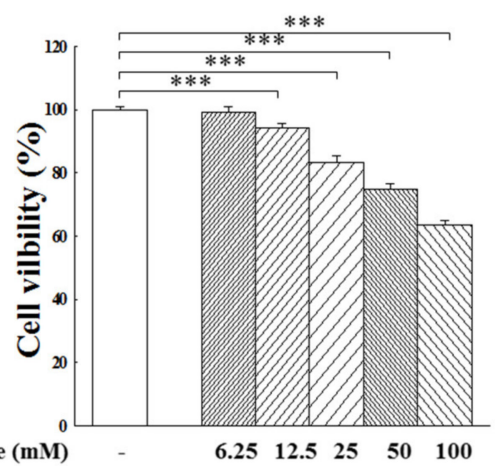

(B)

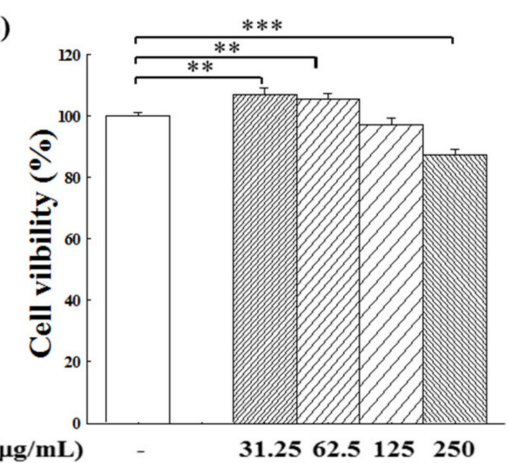

(C)

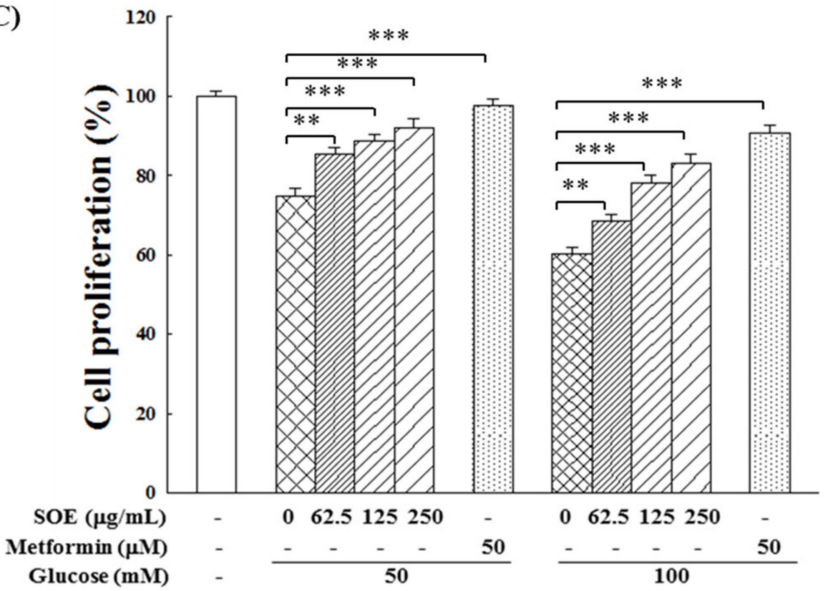

Figure 1. Effects of glucose and SOE on the cell viability and proliferation of RIN-m5f $\beta$-cells. (A) Effect of glucose at different concentrations on the viability of RIN-m5f cells. (B) Effect of SOE at different concentrations on the viability of RIN-m5f cells without adding glucose. (C) Effect of SOE at different concentrations on the proliferation of RIN-m5f cells stimulated by treatment of $50 \mathrm{mM}$ or $100 \mathrm{mM}$ glucose. $\beta$-Cells were cultivated in 96 -well plates at a density of $1 \times 10^{4}$ cells/well for $24 \mathrm{~h}$; then the indicated concentration of glucose and/or SOE was added. After $24 \mathrm{~h}$ treatment, the cell viability was assessed using an MTT assay kit and detected at $570 \mathrm{~nm}$ by an ELISA reader. The control group was the RIN-m5f cells grown without glucose stimulation and SOE treatment. The number of cells at $24 \mathrm{~h}$ cultivation of this group was set as 100\%. The experimental data were calculated from the results of five repeated experiments. The statistically significant differences compared to the control or the vehicle (group 0 ) are expressed as ${ }^{* *} p<0.01$, and ${ }^{* *} p<0.001$. The positive control was $50 \mu \mathrm{M}$ Metformin.

\subsection{Effect on ROS Generation in HG-Stimulated $\beta$-Cells}

Clinical evidence shows that HG can stimulate excessive ROS production in diabetic patients [28]. We examined in this study whether SOE could attenuate this adverse effect. As shown in Figure 2, under the stimulation of 50 or $100 \mathrm{mM}$ glucose, the amount of intracellular ROS increased significantly to $132 \%$ and $141 \%$, respectively. The SOE treatment could effectively and concentration-dependently reduce the generation of intracellular ROS. When the cells treated with SOE at a concentration reached $250 \mu \mathrm{g} / \mathrm{mL}$, ROS dropped to the level close to the control group (no glucose stimulation). 
(A)

\begin{tabular}{|c|c|c|c|c|c|c|}
\hline $\mathrm{SOE}(\mu \mathrm{g} / \mathrm{mL})$ & - & - & 62.5 & 125 & 250 & - \\
\hline Metformin $(\mu \mathrm{M})$ & - & - & - & - & - & 50 \\
\hline Glucose $(50 \mathrm{mM})$ & - & + & + & + & + & + \\
\hline $\mathrm{SOE}(\mu \mathrm{g} / \mathrm{mL})$ & - & - & 62.5 & 125 & 250 & - \\
\hline Metformin $(\mu \mathrm{M})$ & - & - & - & - & - & 50 \\
\hline Glucose $(100 \mathrm{mM})$ & - & + & + & + & + & + \\
\hline
\end{tabular}

(B)

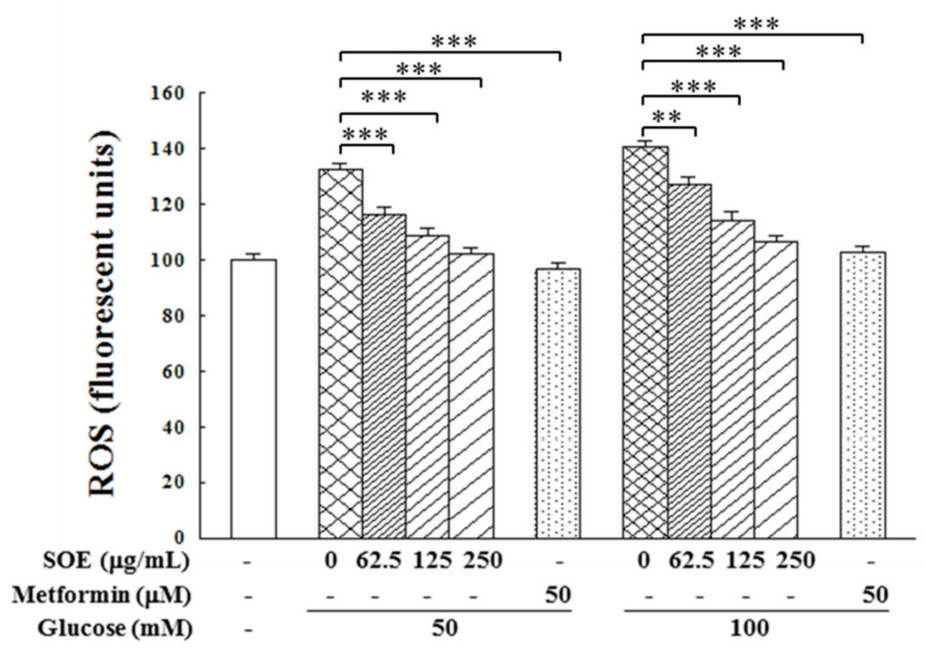

Figure 2. Effect of SOE on the formation of ROS in RIN-m $5 f \beta$-cells under HG-induced conditions. (A) Changes in the intracellular ROS levels indicated by the $\mathrm{DCFH}_{2}-\mathrm{DA}$ fluorescence intensity. (B) Fluorescent quantitation. The $\beta$-cells were cultivated in 96-well plates at a density of $1 \times 10^{5}$ cells/well for $24 \mathrm{~h}$, and the indicated concentration of SOE was added under the stimulation of $50 \mathrm{mM}$ or $100 \mathrm{mM}$ glucose. After $24 \mathrm{~h}$ treatment, the cells were washed with PBS and incubated with $5 \mu \mathrm{M}$ DCF-DA for another $30 \mathrm{~min}$ at room temperature. Fluorescence of this compound was measured by a microplate reader. The experimental data were calculated from the results of five repeated experiments. The statistically significant differences compared with the vehicle (group 0 ) are expressed as ${ }^{* *} p<0.01$, and ${ }^{* * *} p<0.001$. The positive control was $50 \mu \mathrm{M}$ Metformin.

\subsection{Effect on Antioxidant Enzymes in HG-Stimulated $\beta$-Cells}

HG is known to decrease the activity of antioxidant enzymes in diabetic patients [28], we examined in this study whether SOE could maintain the activity of antioxidant enzymes. Figure $3 \mathrm{~A}, \mathrm{C}$ indicate the protective effects of $\mathrm{SOE}$ on the activity of intracellular antioxidant enzymes, including catalase, GPx and SOD, in HG-stimulated $\beta$-cells. HG treatment alone dramatically decreased the activities of catalase, GPx, and SOD. The higher the glucose concentration, the lower the activity of these enzymes. At 50 and $100 \mathrm{mM}$ glucose, the catalase activity decreased to $70.6 \%$ and $48.4 \%$, respectively; the GPx activity decreased to $72.6 \%$ and $59.8 \%$, respectively; the SOD activity decreased to $68.6 \%$ and $57.2 \%$, respectively. However, when SOE was also included in the culture, as shown in the results in Figure $3 \mathrm{~A}-\mathrm{C}$, SOE treatment increased the activity of these three enzymes in the HG-stimulated $\beta$-cells, and the level of increase was in relation to the increase of $\mathrm{SOE}$ concentration. When SOE concentration was at $250 \mu \mathrm{g} / \mathrm{mL}$, the activity of these enzymes was restored to near the normal level. 
(A)

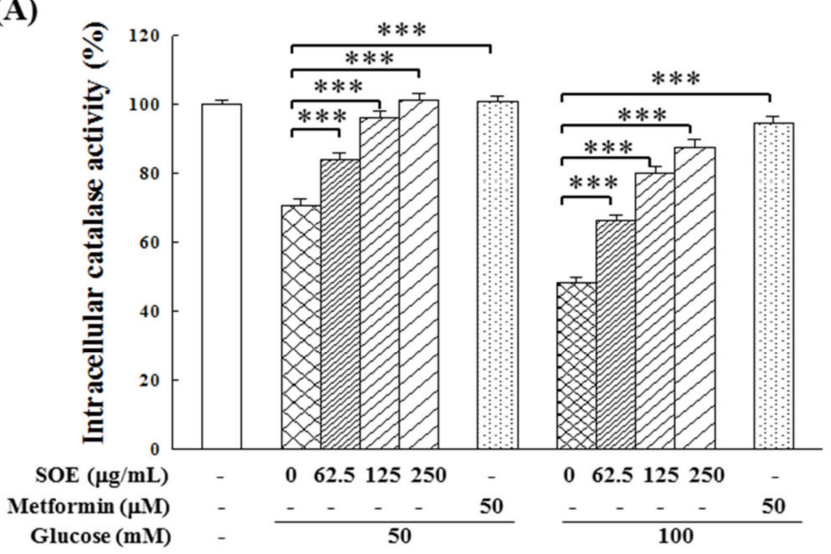

(B)

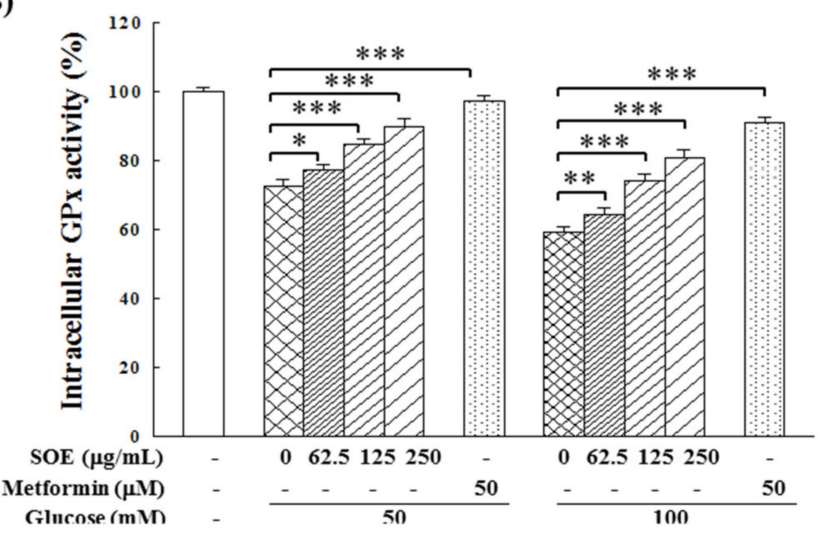

(C)

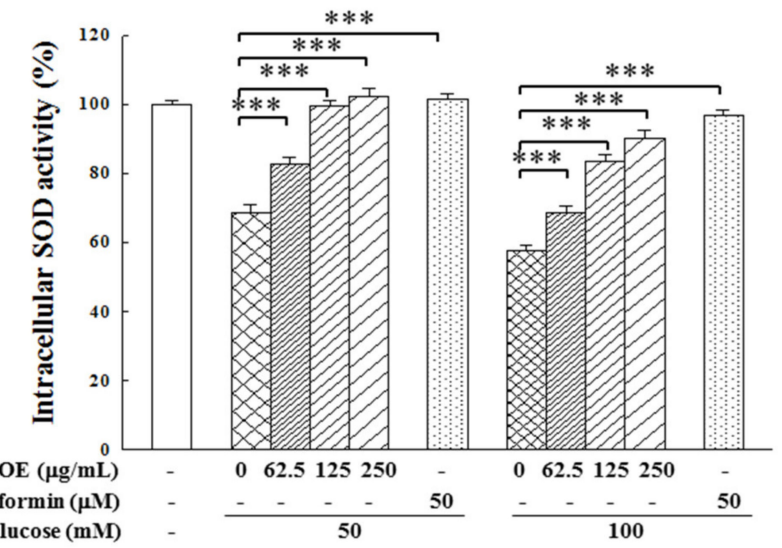

(D)

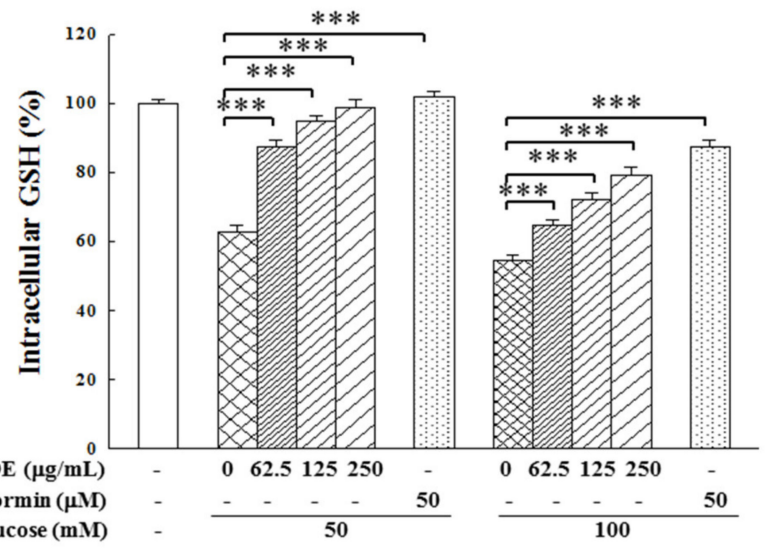

Figure 3. Effect of SOE on the production of antioxidant enzymes and GSH in RIN-m5f $\beta$-cells under HG induction. (A) catalase, (B) GPx, (C) SOD, and (D) GSH. The $\beta$-cells were cultivated in 6-well plates at a density of $5 \times 10^{5}$ cells/well for $24 \mathrm{~h}$, and the indicated concentration of SOE was added under the stimulation of $50 \mathrm{mM}$ or $100 \mathrm{mM}$ glucose. After $24 \mathrm{~h}$ treatment, the cell extracts were prepared according to the manufacturer's instruction. The protein content was measured using the Bicinchoninic Acid Protein Assay Kit. The assay of the activities of catalase, GPx, SOD, and the content of GSH were performed according to manufacturer's instructions with Sigma-Aldrich Assay Kits. The experimental data were calculated from the results of three repeated experiments. The statistically significant differences compared with the vehicle (group 0 ) are expressed as ${ }^{*} p<0.05,{ }^{* *} p<0.01$, and ${ }^{* * *} p<0.001$. The positive control was $50 \mu \mathrm{M}$ Metformin.

Reduced glutathione (GSH) is an antioxidant present in various types of cells. As shown in Figure 3D, glucose concentration at 50 or $100 \mathrm{mM}$ significantly reduced the intracellular GSH content to $62.6 \%$ and $54.4 \%$, respectively. The SOE treatment significantly increased the GSH content concentration-dependently.

To understand whether the increase in the activity of these three antioxidant enzymes was due to the activation of enzyme or to the promotion of enzyme protein production by $\mathrm{SOE}$, we determined the protein expression of these three enzymes in the RIN-m $5 \mathrm{f}$ cells using Western blotting. Results in Figure 4 indicate that the protein expression of catalase, GPx, and SOD decreased to $68 \%, 60 \%$, and $38 \%$, respectively, in cells stimulated with $100 \mathrm{mM}$ glucose. However, when SOE was included in the culture, the protein expression of these three enzymes increased significantly, and the increase was in a concentrationdependent manner. Thus, the increase in the activity of antioxidant enzymes (shown in Figure 3) should be due to the promotion of the formation of these enzymes stimulated by SOE.

\subsection{Effect on Insulin Secretion in HG-Stimulated $\beta$-Cells}

To examine whether glucotoxicity increases dysfunction of insulin secretion, we incubated RIN-m5f cells with HG for $24 \mathrm{~h}$. Results in Figure 5 show that after $24 \mathrm{~h}$ cultivation 
in a $50 \mathrm{mM}$ HG condition, the intracellular insulin secretion rose to $110.1 \%$. When these cells were treated with $\mathrm{SOE}$, the insulin secretion was decreased as SOE concentration increased and returned to the normal value $(101.2 \%)$ when the SOE concentration reached $250 \mu \mathrm{g} / \mathrm{mL}$. On the other hand, when cells were incubated in a higher concentration of glucose $(100 \mathrm{mM})$, insulin secretion dropped to $85.0 \%$. Treatment with SOE prevented the trend and returned the insulin secretion to near the normal value (94.2\%) when the concentration of SOE was $250 \mu \mathrm{g} / \mathrm{mL}$. These findings indicate that SOE possesses the regulation function on pancreatic $\beta$-cell insulin secretion under HG condition.

(A)

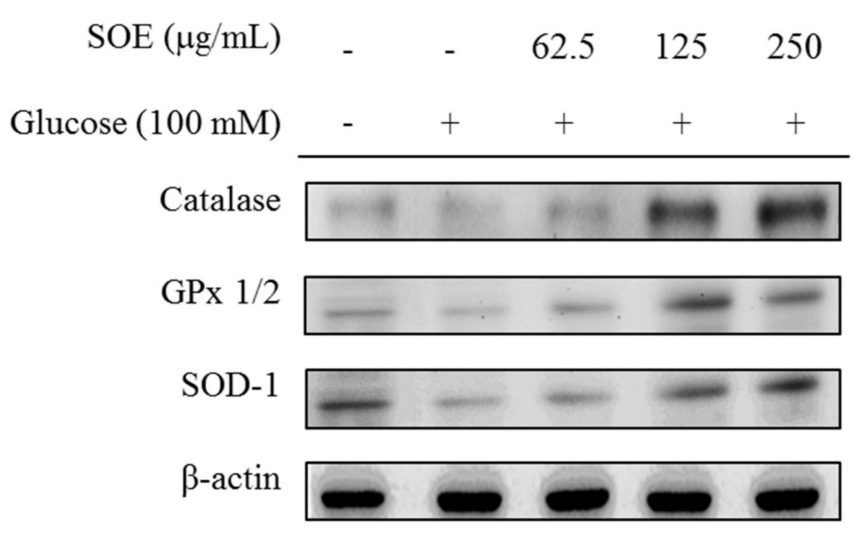

(B)

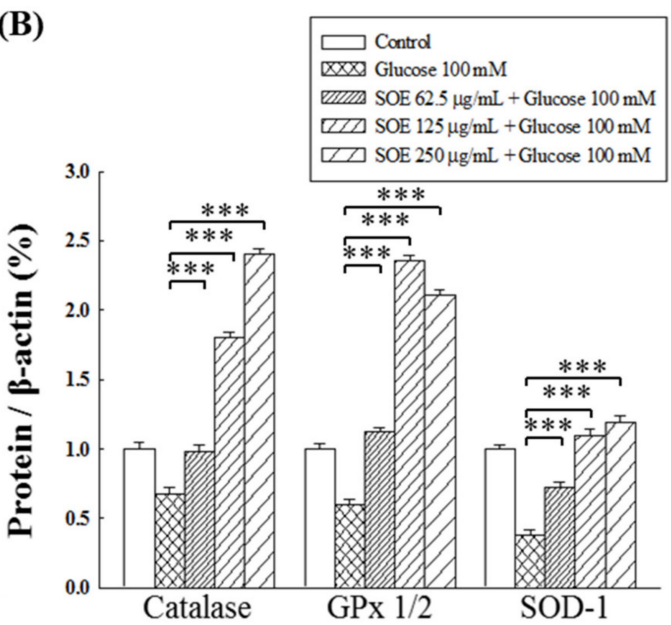

Figure 4. Effect of SOE on the production of antioxidant enzymes (catalase, GPx, and SOD) in RIN-m5f $\beta$-cells under HG stimulation. (A) Changes in protein expression of the three antioxidant enzymes. (B) Densitometric quantitation. The $\beta$-cells were cultivated for $24 \mathrm{~h}$ and then treated with various concentrations of SOE for $24 \mathrm{~h}$ under the stimulation of $100 \mathrm{mM}$ glucose. The obtained cell extracts were subjected to electrophoresis on SDS-PAGE gel, followed by an enzyme immunoassay and ECL for detection. The internal standard was $\beta$-actin. Densitometric analysis was also performed. The experimental data were calculated from the results of three repeated experiments. The statistically significant differences compared with the vehicle (group 0) are expressed as ${ }^{* * *} p<0.001$.

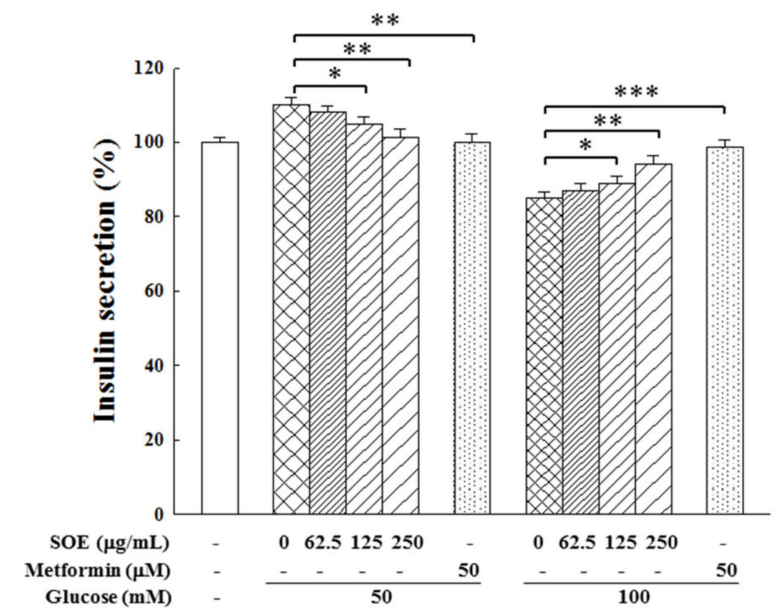

Figure 5. Effect of SOE on insulin secretion in RIN-m5f $\beta$-cells under HG induction. The $\beta$-cells were cultivated at a density of $5 \times 10^{5}$ cells / well for $24 \mathrm{~h}$, and then the specified concentration of SOE was added under the stimulation of $50 \mathrm{mM}$ or $100 \mathrm{mM}$ glucose. After $24 \mathrm{~h}$ treatment, the cell solution was replaced by Krebs-Ringer buffer and conducted the insulin secretion measurement by Rat/Mouse Insulin ELISA Kit. The experimental data were calculated from the results of five repeated experiments. The statistically significant differences compared with the vehicle (group 0 ) are expressed as ${ }^{*} p<0.05,{ }^{* *} p<0.01$, and ${ }^{* * *} p<0.001$. The positive control was $50 \mu \mathrm{M}$ Metformin. 


\subsection{Chemical Composition of SOE}

The chemical composition of SOE was analyzed by HPLC, and its chromatogram is shown in Figure 6. Five ingredients were chlorogenic acid (peak 1), syringic acid (peak 2), $p$-coumaric acid (peak 3), syringaldehyde (peak 4), and kirenol (peak 5). The contents of these five ingredients in SOE are listed in Table 1.
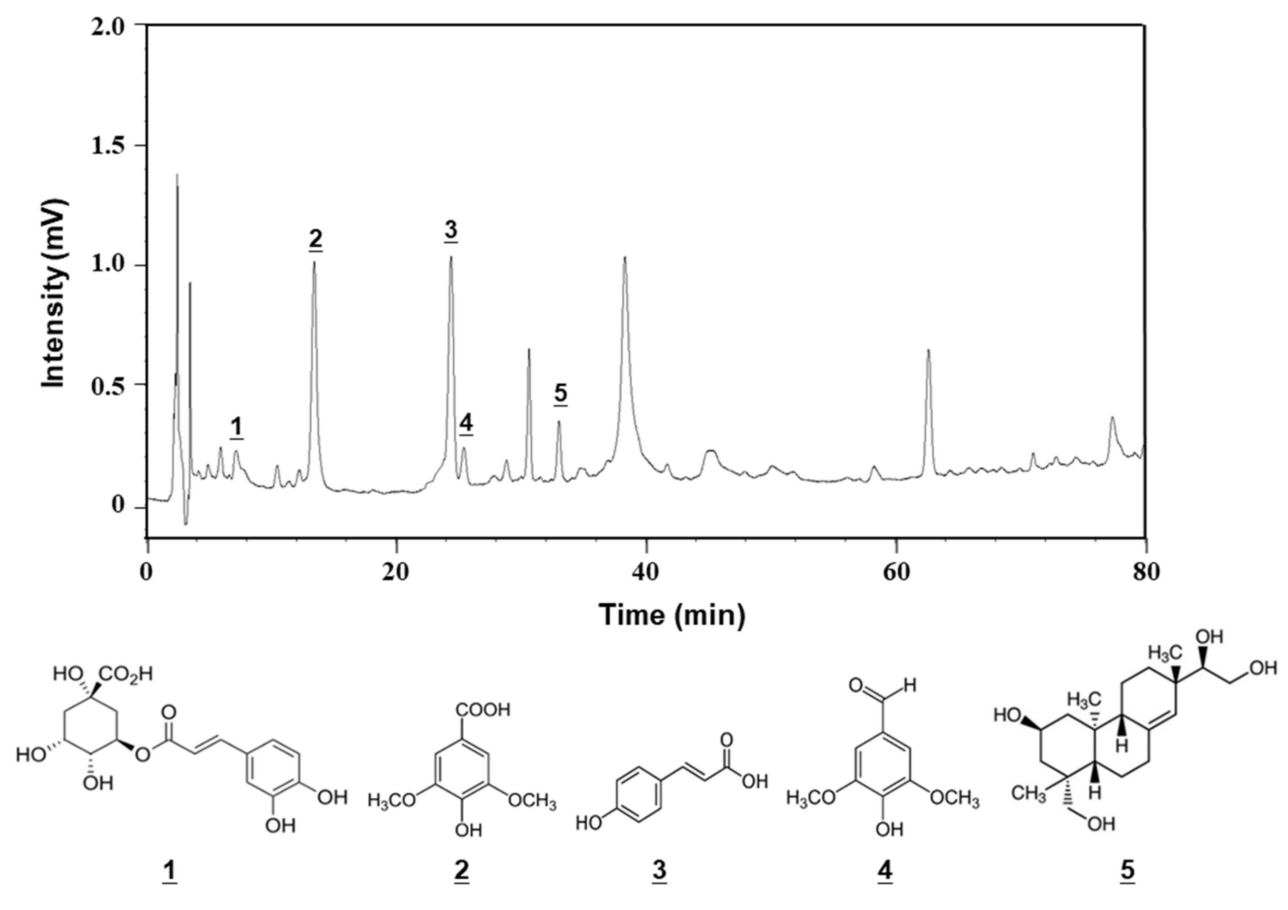

Figure 6. Main ingredients analysis of the SOE by HPLC. Peak 1: chlorogenic acid; peak 2: syringic acid; peak 3: p-coumaric acid; peak 4: syringaldehyde; and peak 5: kirenol. The analyses were performed by a Supelco C18 column, and a gradient of acetonitrile and $0.1 \%$ acetic acid was used as the mobile phase. The compounds were identified with those of reference compounds.

Table 1. Content of the main ingredients in SOE *.

\begin{tabular}{cccc}
\hline No. & Component & $\begin{array}{c}\text { Retention Time } \\
(\mathbf{m i n})\end{array}$ & $\begin{array}{c}\text { Content } \\
(\mathbf{m g} / \mathbf{g} \text { Dry Extract) }\end{array}$ \\
\hline 1 & Chlorogenic acid & 7.2 & $2.04 \pm 0.04$ \\
2 & Syringic acid & 13.4 & $10.76 \pm 0.11$ \\
3 & p-Coumaric acid & 24.4 & $0.70 \pm 0.03$ \\
4 & Syringaldehyde & 25.4 & $0.39 \pm 0.02$ \\
5 & Kirenol & 37.3 & $7.88 \pm 0.08$ \\
\hline
\end{tabular}

* The content of each component was estimated based on the standard curve constructed by the peak area of that reference compound at different concentrations. Data were estimated from three repeated experiments.

\section{Discussion}

Chronic hyperglycemia in diabetic patients promotes the oxidation of glucose in mitochondria, which leads to the formation of excessive free radicals, thereby greatly increasing oxidative stress [28]. The glucotoxicity caused by hyperglycemia can decrease activity of antioxidant enzymes, including catalase, GPx, and SOD [29-31]; exacerbate oxidative stress; induce $\beta$-cell apoptosis and a gradual loss of $\beta$-cell mass and function, leading to insufficient insulin secretion; and result in diabetes $[10,32,33]$. Therefore, an approach to reduce the oxidative stress and apoptosis induced by glucotoxicity is a treatment strategy to reduce the risk of such pathological damage [16]. More and more studies have shown beneficial effects of many plant extracts or phytochemicals on the prevention and treatment of diabetes $[3,14-18,28]$. Previously, SOE was demonstrated to have anti-inflammatory, 
antioxidant activity and can inhibit the activity of $\alpha$-glucosidase, pancreatic lipase and ACE and the formation of AGEs [19,25]. This study investigated the effects of SOE on cell proliferation, intracellular ROS generation, activity of the antioxidant enzymes, and insulin secretion in HG-stimulated RIN-m5f $\beta$-cells.

Results in this study show that exposure of pancreatic $\beta$-cells in HG levels significantly reduced the cell viability (Figure $1 \mathrm{~A}$ ). When $\beta$-cells were treated with SOE alone, SOE promoted the growth of $\beta$-cells when the concentration was lower than $62.5 \mu \mathrm{g} / \mathrm{mL}$ but slightly inhibited the growth of $\beta$-cells when the concentration was higher than $250 \mu \mathrm{g} / \mathrm{mL}$ (Figure 1B). Under the induction of HG (50 or $100 \mathrm{mM}$ glucose), SOE protected the growth of $\beta$ cells (Figure 1C). Previously, it has been shown that SOE is cytotoxic to several human cancer cell lines (the $\mathrm{IC}_{50}$ values were between 87.2 to $179.1 \mu \mathrm{g} / \mathrm{mL}$ ), including RL-95 (endometrial cancer), A549 (lung cancer), HepG2 (hepatoma), FaDu (pharynx squamous cancer), MDA-MB-231 (breast cancer), and LNCaP (prostate cancer). The action of SOE treatment was through arresting the cell growth (e.g., RL-95) in G2/M phase and induced cell apoptosis by up-regulating the expression of Bad, Bak, Bax, caspase-3, -8, and -9 and down-regulating the expression of Bcl-2 and Bcl-xL [23]. In spite of the fact that SOE exhibits cytotoxicity against cancer cells, results in our study demonstrate that SOE can provide a protective effect on the growth of pancreatic $\beta$-cells against HG-induced cytotoxicity.

Glucotoxicity in $\beta$-cells can induce the production of excess ROS, which are free radicals generated from oxygen metabolism in mitochondria. Normal cells have an antioxidant defense system that can neutralize ROS and keep the cells at optimal redox potential to maintain normal cell functions [1,34]. When ROS exceeds the capability of this antioxidant system, which is the case in diabetes, it will stimulate oxidative stress and lead to cell apoptosis and dysfunction $[35,36]$. To date, the application of antioxidants is still an important approach to protect the survival and function of $\beta$-cells [5,37]. In our previous paper, we showed that SOE has a potent antioxidant activity in radical-scavenging of 2,2diphenyl-1-picrylhydrazyl (DPPH) and 2,2'-azino-bis(3-ethylbenzothiazoline-6-sulphonic acid) (ABTS), and we showed that it is a good antioxidant [25]. Indeed, we showed in this study that HG stimulated the production of ROS and that SOE treatment could greatly attenuate the ROS generation to the normal level (Figure 2).

When the expression level of antioxidant enzymes such as catalase (an abundant peroxidase), GPx (a peroxide decomposition enzyme), and SOD (a defense enzyme and scavenger of free radicals) is low in pancreatic islets, pancreatic $\beta$-cells are easily damaged by mitochondrial ROS [33,38]. The enhancement of the activity of catalase, GPx, and SOD can reduce the production of ROS in cells and protect $\beta$-cells and islets from oxidative damage [16,39-41]. GSH is a biological antioxidant that can neutralize ROS and prevent the cell damage caused by free radicals, peroxides, lipid peroxides, and heavy metals. The administration of GSH to SD rats could block the glucose/ROS-induced $\beta$-cell damages [42]. The present study indicates that the treatment of SOE to HG-stimulated pancreatic $\beta$-cells could increase catalase, GPx, and SOD activities and the intracellular GSH level (Figure 3). Since the protein expression of these antioxidant enzymes were significantly increased after SOE treatment, we conclude that the elevation of the antioxidant enzyme activities was mainly due to the increase in the expression of these enzyme proteins (Figure 4).

When the blood glucose level rises, pancreatic $\beta$-cells would secrete insulin to maintain glucose homeostasis. However, chronic hyperglycemia induced-glucotoxicity may cause death and function loss of $\beta$-cell, thereby blocking the production of insulin [36]. This study shows that secretion of insulin in RIN-m5f $\beta$-cells incubated for $24 \mathrm{~h}$ with glucose at a lower concentration $(50 \mathrm{mM})$ was significantly induced but reduced when treated with a higher concentration of glucose $(100 \mathrm{mM})$. It is worth noting that even though the cell growth, the production of ROS and GSH, and the antioxidant enzyme activity in $\beta$-cells were affected when cultured under $50 \mathrm{mM}$ glucose, the insulin secretion function was still maintained at a normal elevated state. This could be due to the fact that pancreatic $\beta$-cells need more time to regulate the insulin secretion function [33], and the HG treatment time 
in this study was only $24 \mathrm{~h}$. However, when the glucose concentration was increased to $100 \mathrm{mM}$, the insulin secretion of $\beta$-cells could no longer be maintained at a normal level.

In this study, we show that SOE can adjust the insulin secretion by $\beta$-cells. In cells cultured in $50 \mathrm{mM}$ glucose condition, $\mathrm{SOE}$ can reduce insulin secretion to the normal level, while under the $100 \mathrm{mM}$ glucose condition, SOE can adjust the insulin secretion upward to return to the normal level (Figure 5). Therefore, SOE has a two-way regulation effect on insulin secretion of the HG-treated $\beta$-cells.

The toxic effect of SOE on cancer cells was caused by inducing apoptosis of cancer cells [23]; however, this study found that SOE has a protective effect on the survival of $\beta$-cells in the HG environment. This phenomenon should be due to the antioxidant effect of SOE alleviating the oxidative stress caused by HG, thereby reducing the cell apoptosis caused by oxidative stress and maintain the normal secretion of insulin.

\section{Materials and Methods}

\subsection{Preparation of $S O E$}

The S. orientalis plant was purchased at Yuanshan Herbal Store (Kaohsiung City, Taiwan). Its nucleotide sequence had been detected and registered in the NCBI's DNA database, the accession number is JN987228 [43]. To prepare SOE, $9.3 \mathrm{~kg}$ of dried S. orientalis aerial parts were crushed and extracted with $47 \mathrm{~L}, 95 \%$ ethanol for $24 \mathrm{~h}$. The extraction was performed three times in total. The collected extraction solutions were pooled together and filtered using No. 1 Whatman filter paper. Then, the filtrate was concentrated by a rotary evaporator (Panchum Scientific, Kaohsiung City, Taiwan), and the resulting extract residue was further dried by a freeze-dryer. A total of $489 \mathrm{~g}$ dry SOE was obtained, a yield of $5.26 \%$. The dry SOE was kept at $-20^{\circ} \mathrm{C}$ before use.

\subsection{Cell Culture and Viability Analysis}

Rat RIN-m5f pancreatic $\beta$-cell line was purchased from Bioresource Collection and Research Center (Hsinchu, Taiwan). The cells were cultured in RPMI 1640 medium supplemented with $10 \%$ fetal bovine serum (FBS) (Gibco Co., Grand Island, NY, USA), $2 \mathrm{mM}$ L-glutamine, $100 \mathrm{U} / \mathrm{mL}$ penicillin, and $100 \mu \mathrm{g} / \mathrm{mL}$ streptomycin, $\mathrm{pH}$ 7.2-7.4. The cells were cultivated $37^{\circ} \mathrm{C}$ in a humidified incubator with $5 \% \mathrm{CO}_{2}$ and $95 \%$ air.

RIN-m5F cells were cultivated in 96-well plates at a density of $1 \times 10^{4}$ cells/well for $24 \mathrm{~h}$. The indicated concentration of SOE (dissolved in dimethyl sulfoxide, DMSO) with or without glucose was then added to the culture. To assure that cell growth would not be affected by DMSO, the final concentration of DMSO in the medium was less than $0.1 \%$. After incubation with SOE and with or without glucose for $24 \mathrm{~h}$, we removed the culture medium and added $100 \mu \mathrm{L}$ of the culture medium containing $0.5 \mathrm{mg} / \mathrm{mL}$ of an MTT Assay Kit (Sigma-Aldrich Chemicals, St. Louis, MO, USA). After incubating the mixture for another $4 \mathrm{~h}$, we removed the medium solution and added $100 \mu \mathrm{L}$ of DMSO. Then, we shook the plate until all crystals were dissolved. We used an ELISA reader (Model 550, Bio-Rad Laboratories, Hercules, CA, USA) to detect the viability of RIN-m5F cells at a wavelength of $570 \mathrm{~nm}$.

\subsection{Assay of Intracellular ROS Level}

The intracellular ROS level (mainly hydrogen peroxide) in oxidative-stressed RIN-m5f cells was measured by the dichlorofluorescein assay (STA-342, Sigma-Aldrich Assay Kit), which uses $2^{\prime}, 7^{\prime}$-dichlorodihydrofluorescein diacetate (DCF-DA) to detect the ROS level. RIN-m5f cells $\left(1 \times 10^{5}\right.$ cells/well $)$ in 96-well plates were first incubated for $24 \mathrm{~h}$, and then replaced the medium with new medium containing specified concentrations of SOE with or without glucose (50 or $100 \mathrm{mM})$. After an additional $24 \mathrm{~h}$ of incubation, the cells were washed with phosphate-buffered saline (PBS) and incubated with $5 \mu \mathrm{M}$ DCF-DA for $30 \mathrm{~min}$ at room temperature. We then measured the level of this compound by fluorescence using a microplate reader at $502 \mathrm{~nm}$ excitation wavelength and $524 \mathrm{~nm}$ emission wavelength (Synergy $^{\mathrm{TM}}$ 2, BioTek, Winooski, VT, USA) 


\subsection{Assay of Antioxidant Enzymes Activity and Reduced Glutathione}

RIN-m5f cells $\left(5 \times 10^{5}\right.$ cells/well) were seeded in 6-well plates and cultured in the complete cell culture medium for $24 \mathrm{~h}$. The medium was then replaced with the same medium containing various concentrations of $\operatorname{SOE}(0,62.5,125$ and $250 \mu \mathrm{g} / \mathrm{mL})$ in the presence of the HG conditions for $24 \mathrm{~h}$. After the treatment, the cell extracts were prepared according to manufacturer's instruction, and the protein content was determined by a Bicinchoninic Acid Protein Assay Kit (Sigma-Aldrich). The activities of catalase, GPx and SOD and the content of GSH were assayed using the Sigma-Aldrich Assay Kits (Catalog number: STA-341, K762-100, STA-340, and STA-312, respectively) following the manufacturer's instructions.

\subsection{Western Blot Assay}

Western blot assay was conducted to detect the effects of SOE on the expression of different antioxidant enzymes, i.e., catalase, SOD, and GPx. The cells treated with glucose and SOE $(0,62.5,125$ and $250 \mathrm{mg} / \mathrm{mL})$ were collected, washed twice with chilled PBS, and lysed with RIPA buffer (Sigma-Aldrich). The protein concentration was determined using the Bradford Protein Assay Kit (Bio-Rad, California, CA, USA). Equal amounts of protein extract were first resolved by $10 \%$ SDS-PAGE gels, and the separated proteins were transferred to nitrocellulose (NC) membranes. Following a blocking step, the proteins were probed with different primary antibodies (purchased from Sigma-Aldrich) against different antioxidant enzymes. The primary antibodies, including dilution conditions, were as follows: rabbit anti-catalase (1:1000), rabbit anti-GPx (1:500), mouse anti-SOD (1:500), and anti- $\beta$-actin (1:5000), which acted as an internal control. Then, the membranes were treated with secondary antibodies $(1: 15,000)$ conjugated with horseradish peroxidase (HRP) for $1 \mathrm{~h}$ at room temperature. Enhanced chemiluminescence (ECL) detection reagents (Sigma-Aldrich) were applied to detect the protein expression. The analysis of relative protein expression was conducted using ChemiDoc XRS+ System (Bio-Rad).

\subsection{Analysis of Insulin Secretion}

To measure the secreted insulin, RIN-m5f cells $\left(5 \times 10^{5}\right.$ cells/well) were seeded in a 6well plate and treated with SOE and HG according to the same procedure described above. After treatment, the medium was carefully removed and changed to Krebs-Ringer buffer (KRB; $129 \mathrm{mM} \mathrm{NaCl}, 10 \mathrm{mM}$ HEPES, $5 \mathrm{mM} \mathrm{NaHCO}_{3}, 4.8 \mathrm{mM} \mathrm{KCl}, 2.5 \mathrm{mM} \mathrm{CaCl}_{2}, 1.2 \mathrm{mM}$ $\mathrm{MgSO}_{4}, 1.2 \mathrm{mM} \mathrm{KH}_{2} \mathrm{PO}_{4}$, and $0.1 \%$ BSA) containing $2.5 \mathrm{mM}$ glucose and $2 \%$ FBS. The culture was kept at $37^{\circ} \mathrm{C}$ for $30 \mathrm{~min}$ and then subjected to insulin secretion measurement by Rat/Mouse Insulin ELISA Kit (Sigma-Aldrich) according to manufacturer's instructions.

\subsection{Analysis of Chemical Composition}

The content of the main components of SOE was determined by HPLC (Shimadzu, Kyoto, Japan) using a C18 column $(5 \mu \mathrm{m}, 250 \mathrm{~mm} \times 4.6 \mathrm{~mm}$; Supelco, Bellefonte, PA, USA). The mobile phase was acetonitrile (solvent $\mathrm{A}$ ) and $0.1 \%$ acetic acid aqueous solution (solvent B), and a gradient elution was performed. The extract was dissolved in methanol and filtered with a $0.22 \mu \mathrm{m}$ filter. The solvent gradient included 0-18 $\min (12-14 \% \mathrm{~A})$, $18-22 \min (14-17 \% \mathrm{~A}), 22-50 \min (17-20 \% \mathrm{~A})$, and $50-80 \min (20-35 \% \mathrm{~A})$. The flow rate, sample injection volume, and the detection wavelength were $1.0 \mathrm{~mL} / \mathrm{min}, 30 \mu \mathrm{L}$, and $320 \mathrm{~nm}$, respectively. These compounds were identified by comparing their retention time with those of the reference compounds (Sigma-Aldrich). The quantification of these components was carried out by using a linear regression standard curve constructed by the Microsoft Excel software (Office 2019, Microsoft Software, Redmond, WA, USA).

\subsection{Statistical Analysis}

All experiments were performed for three to five independent replicates. Experimental data are presented as mean \pm standard deviation (SD). Student's $t$-test was used to analyze statistical differences. The statistical analysis was carried out using Microsoft Excel software. 
This study shows that SOE has an effective protective effect on the proliferation of RIN-m5f pancreatic $\beta$ cells induced by HG

\section{Conclusions}

In this study, an effective protective effect of SOE on the proliferation of RIN-m5f pancreatic $\beta$-cells induced by HG was demonstrated. We found that SOE treatment could effectively decrease the generation of intracellular ROS and increase the activities of catalase, GPx, SOD, and GSH content in HG-stimulated cells to reduce oxidative stress. SOE can also regulate the insulin secretion in pancreatic $\beta$-cells under HG conditions. Overall, the results of this study show that SOE can reduce oxidative stress and cell death caused by glucotoxicity under HG stimulation and has a protective effect on pancreatic $\beta$-cells.

Author Contributions: Conceptualization, C.-C.C. and S.-W.W.; methodology, J.-Y.H. and Y.-C.L.; formal analysis, C.-F.H.; investigation, T.-H.C. and Y.-L.C.; resources, C.-C.C. and J.-Y.H.; writingoriginal draft preparation, C.-F.H. and S.-W.W.; writing-review and editing, C.-C.C. and J.-Y.H.; visualization, Y.-C.L.; supervision, C.-C.C.; project administration, C.-C.C. and S.-W.W.; funding acquisition, C.-C.C. and J.-Y.H. All authors have read and agreed to the published version of the manuscript.

Funding: This research was funded by E-Da Hospital, Taiwan (EDAHI108002), I-Shou University, Taiwan (ISU-109-01-14A), and the Ministry of Science and Technology of Taiwan (MOST 107-2221-E214-016).

Institutional Review Board Statement: Not applicable.

Informed Consent Statement: Not applicable.

Data Availability Statement: Data are contained within the article.

Conflicts of Interest: The authors declare no conflict of interest.

\section{References}

1. Bensellam, M.; Laybutt, D.R.; Jonas, J.C. The molecular mecha nisms of pancreatic $\beta$-cell glucotoxicity: Recent findings and future research directions. Mol. Cell Endocrinol. 2012, 364, 1-27. [CrossRef] [PubMed]

2. Imamura, F.; Mukamal, K.J.; Meigs, J.B.; Luchsinger, J.A.; Ix, J.H.; Siscovick, D.S.; Mozaffarian, D. Risk factors for type 2 diabetes mellitus preceded by $\beta$-cell dysfunction, insulin resistance, or both in older adults. Am. J. Epidemiol. 2013, 177, 1418-1429. [CrossRef]

3. Moens, C.; Bensellam, M.; Himpe, E.; Muller, C.J.F.; Jonas, J.C.; Bouwens, L. Aspalathin protects insulin-producing $\beta$ cells against glucotoxicity and oxidative stress-induced cell death. Mol. Nutr. Food Res. 2020, 64, e1901009. [CrossRef] [PubMed]

4. Ajith, T.A.; Vinodkumar, P. Advanced glycation end products: Association with the pathogenesis of diseases and the current therapeutic advances. Curr. Clin. Pharmacol. 2016, 11, 118-127. [CrossRef] [PubMed]

5. Chang, C.C.; Yuan, W.; Roan, H.Y.; Chang, J.L.; Huang, H.C.; Lee, Y.C.; Tsay, H.J.; Liu, H.K. The ethyl acetate fraction of corn silk exhibits dual antioxidant and anti-glycation activities and protects insulin-secreting cells from glucotoxicity. BMC Complement. Altern. Med. 2016, 16, 432. [CrossRef] [PubMed]

6. Rani, N.; Bharti, S.; Bhatia, J.; Nag, T.C.; Ray, R.; Arya, D.S. Chrysin, a PPAR- $\gamma$ agonist improves myocardial injury in diabetic rats through inhibiting AGE-RAGE mediated oxidative stress and inflammation. Chem. Biol. Interact. 2016, 250, 59-67. [CrossRef] [PubMed]

7. Butler, A.E.; Janson, J.; Bonner-Weir, S.; Ritzel, R.; Rizza, R.A.; Butler, P.C. $\beta$-Cell deficit and increased $\beta$-cell apoptosis in humans with type 2 diabetes. Diabetes 2003, 52, 102-110. [CrossRef] [PubMed]

8. Lim, M.; Park, L.; Shin, G.; Hong, H.; Kang, I.; Park, Y. Induction of apoptosis of $\beta$ cells of the pancreas by advanced glycation end-products, important mediators of chronic complications of diabetes mellitus. Ann. N. Y. Acad. Sci. 2008, 1150, 311-315. [CrossRef] [PubMed]

9. Rashid, M.A.; Lee, S.; Tak, E.; Lee, J.; Choi, T.G.; Lee, J.W.; Kim, J.B.; Youn, J.H.; Kang, I.; Ha, J.; et al. Carbonyl reductase 1 protects pancreatic $\beta$-cells against oxidative stress-induced apoptosis in glucotoxicity and glucolipotoxicity. Free Radic. Biol. Med. 2010, 49, 1522-1533. [CrossRef] [PubMed]

10. Brun, T.; Maechler, P. Beta-cell mitochondrial carriers and the diabetogenic stress response. Biochim. Biophys. Acta 2016, 1863, 2540-2549. [CrossRef]

11. Stefano, G.B.; Challenger, S.; Kream, R.M. Hyperglycemia-associated alterations in cellular signaling and dysregulated mitochondrial bioenergetics in human metabolic disorders. Eur. J. Nutr. 2016, 55, 2339-2345. [CrossRef] [PubMed] 
12. Kharroubi, I.; Ladriere, L.; Cardozo, A.K.; Dogusan, Z.; Cnop, M.; Eizirik, D.L. Free fatty acids and cytokines induce pancreatic beta-cell apoptosis by different mechanisms: Role of nuclear factor- $\mathrm{KB}$ and endoplasmic reticulum stress. Endocrinology 2004, 145, 5087-5096. [CrossRef] [PubMed]

13. Harmon, J.S.; Stein, R.; Robertson, R.P. Oxidative stress-mediated, posttranslational loss of MafA protein as a contributing mechanism to loss of insulin gene expression in glucotoxic $\beta$ cells. J. Biol. Chem. 2005, 280, 11107-11113. [CrossRef] [PubMed]

14. Mohamed, E.A.; Yam, M.F.; Ang, L.F.; Mohamed, A.J.; Asmawi, M.Z. Antidiabetic properties and mechanism of action of Orthosiphon stamineus Benth bioactive sub-fraction in streptozotocin-induced diabetic rats. J. Acupunct. Meridian Stud. 2013, 6, 31-40. [CrossRef] [PubMed]

15. Shivanna, N.; Naika, M.; Khanum, F.; Kaul, V.K. Antioxidant, anti-diabetic and renal protective properties of Stevia rebaudiana. J. Diabetes Complicat. 2013, 27, 103-113. [CrossRef] [PubMed]

16. Park, M.H.; Han, J.S. Padina arborescens extract protects high glucose-induced apoptosis in pancreatic $\beta$ cells by reducing oxidative stress. Nutr. Res. Pract. 2014, 8, 494-500. [CrossRef] [PubMed]

17. Zhang, Y.; Ren, C.J.; Lu, G.B.; Mu, Z.M.; Cui, W.Z.; Gao, H.J.; Wang, Y.W. Anti-diabetic effect of mulberry leaf polysaccharide by inhibiting pancreatic islet cell apoptosis and ameliorating insulin secretory capacity in diabetic rats. Int. Immunopharmacol. 2014 22, 248-257. [CrossRef]

18. Park, J.E.; Seo, Y.; Han, J.S. HM-Chromanone isolated from Portulaca oleracea L. protects INS-1 pancreatic $\beta$ cells against glucotoxicity-induced apoptosis. Nutrients 2019, 11, 404. [CrossRef]

19. Hong, Y.H.; Weng, L.W.; Chang, C.C.; Hsu, H.F.; Wang, C.P.; Wang, S.W.; Houng, J.Y. Anti-inflammatory effects of Siegesbeckia orientalis ethanol extract in in vitro and in vivo models. BioMed Res. Int. 2014, 2014, 329712. [CrossRef] [PubMed]

20. Nguyen, T.D.; Thuong, P.T.; Hwang, I.H.; Hoang, T.K.; Nguyen, M.K.; Nguyen, H.A.; Na, M. Anti-hyperuricemic, antiinflammatory and analgesic effects of Siegesbeckia orientalis L. resulting from the fraction with high phenolic content. BMC Complement. Altern. Med. 2017, 17, 191. [CrossRef] [PubMed]

21. Sun, H.X.; Wang, H. Immunosuppressive activity of the ethanol extract of Siegesbeckia orientalis on the immune responses to ovalbumin in mice. Chem. Biodivers. 2006, 3, 754-761. [CrossRef]

22. Wang, J.P.; Luo, Q.; Ruan, J.L.; Chen, Y.A.; Chen, M.X. Effect of Siegesbeckia orientalis L. on cervical cancer HeLa cell in vitro. Her. Med. 2009, 28, 45-46.

23. Chang, C.C.; Hsu, H.F.; Huang, K.H.; Wu, J.M.; Kuo, S.M.; Ling, X.H.; Houng, J.Y. Anti-proliferative effects of Siegesbeckia orientalis ethanol extract on human endometrial RL-95 cancer cells. Molecules 2014, 19, 19980-19994. [CrossRef] [PubMed]

24. Chang, C.C.; Ling, X.H.; Hsu, H.F.; Wu, J.M.; Wang, C.P.; Yang, J.F.; Fang, L.W.; Houng, J.Y. Siegesbeckia orientalis extract inhibits TGF $\beta 1$-induced migration and invasion of endometrial cancer cells. Molecules 2016, 21, 1021. [CrossRef] [PubMed]

25. Hung, W.C.; Ling, X.H.; Chang, C.C.; Hsu, H.F.; Wang, S.W.; Lee, Y.C.; Luo, C.; Lee, Y.T.; Houng, J.Y. Inhibitory effects of Siegesbeckia orientalis extracts on advanced glycation end products formation and key enzymes related to metabolic syndrome. Molecules 2017, 22, 1785. [CrossRef]

26. Piro, S.; Rabuazzo, A.M.; Renis, M.; Purrello, F. Effects of metformin on oxidative stress, adenine nucleotides balance, and glucose-induced insulin release impaired by chronic free fatty acids exposure in rat pancreatic islets. J. Endocrinol. Investig. 2012, $35,504-510$.

27. Adeshara, K.; Tupe, R. Antiglycation and cell protective actions of metformin and glipizide in erythrocytes and monocytes. Mol. Biol. Rep. 2016, 43, 195-205. [CrossRef]

28. Wu, C.H.; Hsieh, H.T.; Lin, J.A.; Yen, G.C. Alternanthera paronychioides protects pancreatic $\beta$-cells from glucotoxicity by its antioxidant, antiapoptotic and insulin secretagogue actions. Food Chem. 2013, 139, 362-370. [CrossRef] [PubMed]

29. Robertson, R.P. Chronic oxidative stress as a central mechanism for glucose toxicity in pancreatic islet $\beta$ cells in diabetes. J. Biol. Chem. 2004, 279, 42351-42354. [CrossRef] [PubMed]

30. Robertson, R.P.; Harmon, J.S.; Tran, P.O.; Poitout, V. $\beta$-Cell glucose toxicity, lipotoxicity, and chronic oxidative stress in type 2 diabetes. Diabetes 2004, 53 (Suppl. 1), S119-S124. [CrossRef] [PubMed]

31. Lenzen, S. Oxidative stress: The vulnerable $\beta$-cell. Biochem. Soc. Trans. 2008, 36, 343-347. [CrossRef]

32. Lowell, B.B.; Shulman, G.I. Mitochondrial dysfunction and type 2 diabetes. Science 2005, 307, 384-387. [CrossRef]

33. Lim, S.; Rashid, M.A.; Jang, M.; Kim, Y.; Won, H.; Lee, J.; Woo, J.T.; Kim, Y.S.; Murphy, M.P.; Ali, L.; et al. Mitochondria-targeted antioxidants protect pancreatic $\beta$-cells against oxidative stress and improve insulin secretion in glucotoxicity and glucolipotoxicity. Cell. Physiol. Biochem. 2011, 28, 873-886. [CrossRef] [PubMed]

34. Chae, H.; Gilon, P. Can tea extracts exert a protective effect against diabetes by reducing oxidative stress and decreasing glucotoxicity in pancreatic $\beta$-cells? Diabetes Metab. J. 2015, 39, 27-30. [CrossRef]

35. Robertson, R.P.; Zhou, H.; Zhang, T.; Harmon, J.S. Chronic oxidative stress as a mechanism for glucose toxicity of the $\beta$ cell in type 2 diabetes. Cell Biochem. Biophys. 2007, 48, 139-146. [CrossRef]

36. Wang, Y.; Li, M.; Yu, X.; He, S.; Wu, X.; Wang, Y. Mulberry leaf flavonoids protect against glucotoxicity-induced INS-1 cell apoptosis. J. Tradit. Chin. Med. 2019, 39, 153-159.

37. Masuda, Y.; Vaziri, N.D.; Li, S.; Le, A.; Hajighasemi-Ossareh, M.; Robles, L.; Foster, C.E.; Stamos, M.J.; Al-Abodullah, I.; Ricordi, C.; et al. The effect of Nrf2 pathway activation on human pancreatic islet cells. PLoS ONE 2015, 10, e0131012.

38. Tiedge, M.; Lortz, S.; Drinkgern, J.; Lenzen, S. Relation between antioxidant enzyme gene expression and antioxidative defense status of insulin-producing cells. Diabetes 1997, 46, 1733-1742. [CrossRef] 
39. Grankvist, K.; Marklund, S.; Täljedal, I.B. Superoxide dismutase is a prophylactic against alloxan diabetes. Nature 1981, 294, 158-160. [CrossRef] [PubMed]

40. Robertson, R.P.; Harmon, J.S. Pancreatic islet $\beta$-cell and oxidative stress: The importance of glutathione peroxidase. FEBS Lett. 2007, 581, 3743-3748. [CrossRef] [PubMed]

41. Krause, M.S.; McClenaghan, N.H.; Flatt, P.R.; de Bittencourt, P.I.; Murphy, C.; Newsholme, P. L-Arginine is essential for pancreatic $\beta$-cell functional integrity, metabolism and defense from inflammatory challenge. J. Endocrinol. 2011, 211, 87-97. [CrossRef]

42. Zhang, J.; An, H.; Ni, K.; Chen, B.; Li, H.; Li, Y.; Sheng, G.; Zhou, C.; Xie, M.; Chen, S.; et al. Glutathione prevents chronic oscillating glucose intake-induced $\beta$-cell dedifferentiation and failure. Cell Death Dis. 2019, 10, 321. [CrossRef] [PubMed]

43. Hsu, H.F.; Chen, Z.H.; Chang, S.F.; Wang, C.P.; Chiou, S.J.; Yen, J.H.; Chang, C.C.; Tsai, Y.D.; Fang, L.W.; Houng, J.Y. Evaluating the anti-metastatic potential of Anisomeles indica extract by using human oral squamous carcinoma FaDu cells. Afr. J. Pharm. Pharmacol. 2012, 6, 1782-1791. 